\title{
Udgravningerne i Hedeby.
}

\section{En Oversigt over deres Resultater.}

1. Ud g ravningerne ved Ha d d e b y Nor. Fra 1930 har tyske Forhistorikere genoptaget Udgravningerne paa Bopladsen ved Haddeby Nor med Resultater, der har fremkaldt Interesse blandt de lærde i hele Nordeuropa; i Tyskland og især i Danmark har de vakt Opmærksomhed langt udover de lærdes Kreds. Disse Udgravninger er langtfra afsluttet, og det er $\epsilon$ ndnu for tidligt at skrive deres Historie. Men allerede de hidtil vundne Resultater er i Enkeltheder saa betydningsfulde for vor Forstaaelse af Egnens ældre Historie og $i$ det hele saa oplysende for Nordeuropas Historie i ældre Middelalder, at de fortjener at gøres tilgængelige for alle interesserede. Den følgende Oversigt skal kun gælde som en foreløbig Redegørelse for, hvad der hidtil er naaet. Hovedvægten lægges paa de allersidste Aars Resultater; hvad Gravningerne før 1930 har bragt, omtales kortere, da man herom kan finde Oplysning i Dr. Vilh. la Cours Fremstilling i den store Senderjyllandshistorie ${ }^{1}$ ).

2. Initiativet til U d g ravningerne. Det er tyske Videnskabsmænd, der har ledet Udgravningerne ved Haddeby Nor. Initiativet til dem er dog kommet fra en dansk Videnskabsmand. I sin store Fremstilling af Danmarks Forhistorie "Vor Oldtid“ i 1897 omtalte S o p h u s M ü ll er (1846-1934) den mægtige Halvkredsvold vest for Haddeby Nor. Han paaviste, at Pladsen mellem Volden og Noret - wdybt inde i Landet, men dog med Vandforbindelse til Havet, - ved et Nor, som gav en sikker Havn, og hvis snævre Aabning det var let at spærre var som skabt til en By i Oldtiden.')

Det var paa Sophus Müllers Opfordring, at "Schleswigholsteinisches Museum vaterländischer Altertümer« i Kiel i

1) Sønderjyllands Historie fremstillet for det danske Folk, I, 1930. S. $251 \mathrm{ff}$.

$\left.{ }^{2}\right)$ S o p h. M ü lle r: Vor Oldtid 1897, S. 632 ff. 
Sommeren 1900 ved Dr. S p li e t $\mathrm{h}$ foretog nogle Provegravninger indenfor Halvkredsvolden, der gav overraskende rigt Udbytte. Man konstaterede et henved $1 \mathrm{~m}$ dybt Kulturlag, der rummede Rester af Væggenes Lerklining, af forarbejdet Hjortetak, Skaar af Lerkar, Perler af Glas og Emaille m. m. Kielermuseets Leder, J. Mest orf, der offentliggjorde Resultatet, saa heri Vidnesbyrd om, at Halvkredsvolden havde rummet en By, der havde udgjort et Industri- og Handelscentrum i Tiden kort før Aar 1000. ${ }^{3}$ )

Endnu i 1900 udtalte Sophus Müller den Antagelse, at det var $\mathrm{H}$ e $\mathrm{d}$ e b y, der i 10. Aarhundrede havde ligget indenfor Halvkredsvolden, og at Tilstedeværelsen af denne faste Plads havde haft sin Betydning ved Anlæget af Danevirke.")

Den følgende Menneskealders Forskning har bekræftet Sophus. Müllers Antagelse. I 1931 kunde den nuværende Leder af Kielermuseet og af Hedebyudgravningerne udtale: "Der Gelehrte, der für die heutige Wissenschaft Hedeby wieder entdeckt hat, ist Sophus Müller. $\left.\aleph^{5}\right)$

3. Udgravningerne efter 1901 . Opmuntret af Dr. Splieths vellykkede Prøvegravning fortsatte Kielermuseet de følgende Aar Undersøgelsen af Bypladsen. Hist og her gravedes smaa Prøvegrøfter, der udvidedes, naar man stødte paa større Objekter. Efterhaanden fik de aarlige Undersøgelser et større Omfang, indtil de fra 1915 afbrødes paa Grund af Verdenskrigen. Der gravedes atter i 1921, men derefter genoptoges Gravningerne først i 1930. Alle Undersøgelser fra 1901 til 1921 lededes af Kielermuseets Direktør i disse Aar, Dr. Fr. K n o r r.

Allerede disse orienterende Undersøgelser gav et rigt videnskabeligt Udbytte. Halvkredsvolden undersøgtes; det viste sig, at den i Oldtiden havde udgjort et Virke af Jord og Træ, gennemskaaret af to Portaabninger; de tilstødende Voldpartier undersøgtes, og man blev klar over deres Afhængighed af Halv-

3) J. Mestorf i Mitteilungen des Athropologischen Vereins in Schl.-H. 14 H., 1901, S. 19 ff.

4) S o p h. M ü l l e r i Aarbøger f. nord. Oldkyndighed 1900. S. 254.

5) G. Schw antes i Zeitschrift für Ethnologie 1931, S. 234. 
kredsvolden; tæt udenfor Halvkredsvolden fremdroges en Baadkammergrav af svensk Præg; indenfor Volden udgravedes Husrester, Brønde, Grave, men især i Tusindvis af Oldsager, navnlig $i$ "Industrikvarteret ."). $^{8}$.

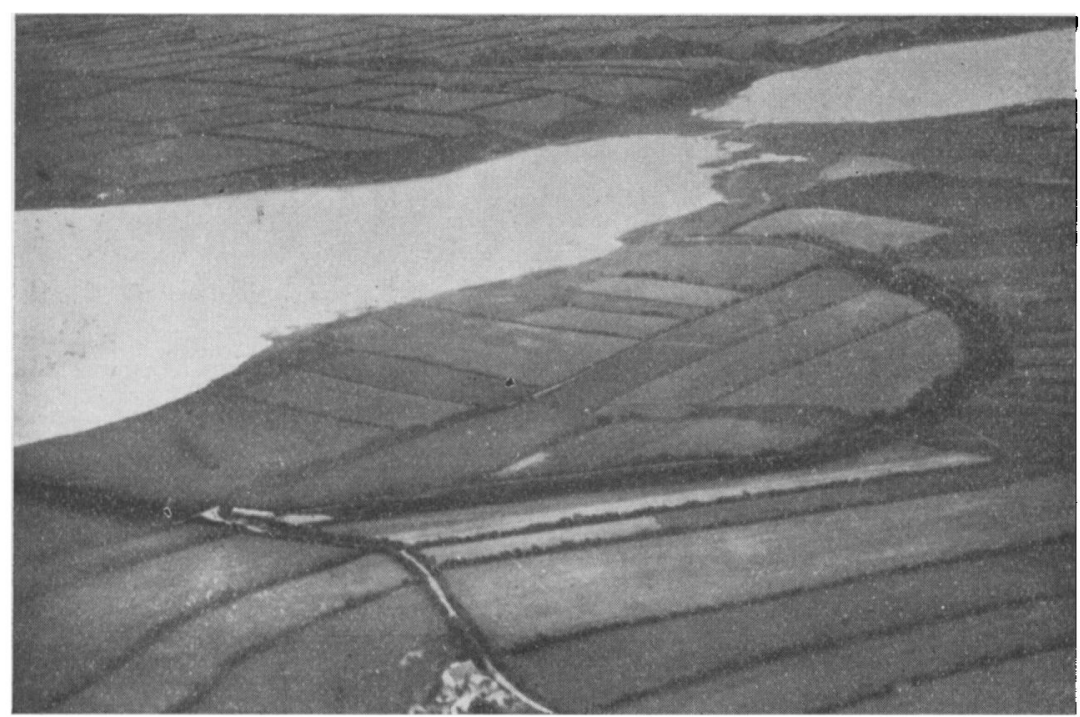

Fig. 1. Halvkredsvolden ved Haddeby Nor, set fra Lutten. I Baggrunden til huje Selk Nor. $f$ Baubehörde Hamburg fot.

Kun en ringe Brøkdel af det Materiale, der fremdroges ved Knorrs Gravninger, er publiceret. Men af dets Rigdom kan man faa et Indtryk ved et Besøg i Hedebysalen i Kielermuseet. I Montrerne ses hjemlige og importerede Lervarer, - Smeltedigler og Støbeforme, store importerede Møllestene og smaa hjemmegjorte Spindestene, Tænger og Hamre, Vægtskaale og Lodder, Vaaben og Smykker o. m. a., der tilsammen giver Beskueren et Indtryk af Stedets Betydning henimod Aar 1000.

En systematisk udtømmende Undersøgelse af Bypladsen toges dog først op i 1930 paa Initiativ af Historikeren Professor

b) Beretninger i Mitteilungen d. anthrop. Vereins f. Schl.-H. 1902, S. 25 ff., 1911, S. 68 ff. Jfr. Schwantes' Meddelelse af Knorrs Resultater i Beretningen fra Arkæologkongressen i Riga 1930 (Congressus II Archæol. Rige 1930, S. 217 ff). Oversigt af Fr. Ḱnorr i lleimatbuch Schleswig 1924, S. $27 \mathrm{ff}$. 
O. Scheel og af Arkæologen Professor G. Schwantes, der imdilertid var blevet Leder af "Museum vorgeschichtlicher Altertümer" i Kiel. I de følgende Aar er Udgravningerne blevet fortsat under Ledelse af Professor Schwantes og hans Medhjælper, Dr. Herbert Jankuhn.

Undersøgelsen af Bypladsen, der hovedsagelig bekostes af offentlige Midler, er anlagt paa langt Sigt. Den 28 ha store Byplads mod Øst begrænset af Haddehy Nor, mod Nord, Vest og Syd af Halvkredsvoldens Bue, gennemkrydses af to $1 \mathrm{~m}$ brede Søgegrafter, den ene fra Volden i Vest til Noret i Øst, den anden parallel med Vejen, der fører fra NV. til Sø. over Pladsen. De to Grøfter skærer hinanden i en ret Vinkel. Disse Søgegrøfter skaffer et vist Overblik over Bebyggelsen og danner Udgangspunkter for Fladegravninger, hvor der er Grund til at udvide

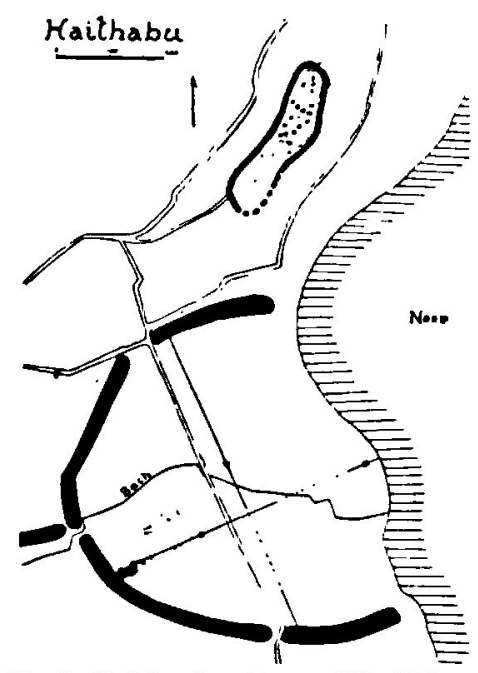

Fig. 2. Halokredsvolden ved Haddeby Nor. Inden for Halvkredsuolden er Gratter og Felter tra Gravningerne 1930-33 afsat

Feltet. Inden for Undersøgelsesomraaderne afskrælles Jorden forsigtigt i tynde Flager; Kulturlagene, "den sorte Jord", der er 1/3 til $2 \mathrm{~m}$ tykke, skiller sig paa Pladsens vestlige Del skarpt ud fra Undergrundens lyse Hedesand. I dette lyse Sand aftegner Omridsene af Fundamenter til Træbygninger, der engang har staaet paa Stedet, sig ganske skarpt som mørke Striber. Undersøgelsen heraf gennemføres med ægte tysk Grundighed og Præcision. Ved Afdækning af Flader indtegnes og fotograferes Lagene med $10 \mathrm{~cm}$ 's Mellemrum, ved Hustomter med $5 \mathrm{~cm}$ 's Afstand!

Det kan ikke undre, at Undersøgelsen af Bypladsen med denne Grundighed maa antages at komme til at strække sig over adskillige Aar, ja maaske Aartier! Men i Kraft af samme 
Grundighed har de sidste Aars Gravninger muliggjort Iagttagelser af Enkeltheder af stor videnskabelig Betydning.

Det er først ved Udgravningerne fra 1930, at man har konstateret Hustomter af forskellig Art. Allerede ved de ældre Udgravninger var man stødt paa en stor Gravplads rummende Skeletter uden Gravgods; i 1930 og følgende Aar fremdrog man Kammergrave med rigt Gravgods efter hedensk Skik. Man har fastslaaet, at største Delen af Omraadet mellem Volden og Noret har været bebygget, og man har fundet Mønter, der tyder paa, at Bebyggelsen af Stedet gaar tilbage til det 9. Aarhundredes forste Halvdel og har vedvaret til henved Midten af det 11. Aarhundrede.

En indgaaende Redegørelse for Udgravningernes Resultater er under Forberedelse fra tysk side. En foreløbig Oversigt over de sidste Aars Resultater er givet i mindre Afhandlinger paa Tysk af Prof. Sch wantes og Dr. Jank uhn, paa Dansk af Dr. la Cour, der har taget Del i en Række af Undersogelserne. Paa dette Grundlag bygger den følgende Fremstilling af Udgravningsresultaterne. $\left.{ }^{7}\right)$

4. Fæ s tn ing e n $\mathrm{H}$ e d e b y. Bypladsen ved Haddeby Nor er mod Landsiden beskyttet af en Vold, der fra Norets vestlige Bred krummer sig i en Halvcirkel paa 1310 m Længde til et ca. $600 \mathrm{~m}$ sydligere Punkt paa Norets Vestside. Af alle Voldanlægene ved Slien er denne $\mathrm{Halvkredsvold} \mathrm{det} \mathrm{mest}$ imponerende. "Der findes ikke $i$ hele Norden et Oldtidsanlæg af tilsvarende Mægtighed og betagende Alvor" (Vilh. la Cour). I

7) Den følgende Redegørelse er i det vasentlige ført op til 1934; dette har været muligt, fordi Dr. Jankuhn velvilligt har ladet mig benytte det foreliggende Manuskript til 1. Bd. af det store Værk: D i e A usgrabungen in $\mathrm{Ha}$ ithabu. Herfor og for Overladelsen af Fotografier fra Udgravningerne til Brug for nærværende Redegørelse skylder jeg Dr. Jankuhn Tak. De benyttede Redegørelser er:

G. S c h w a n t e s: Führer durch Haithabu. Schleswig 1932. «

Die Ausgrabungen in Haithabu, Zeitschrift $f$. Ethnologie 1931, S. 234 ff.

H. J a $\mathrm{n}$ u h n: Die Ausgrabungen i Haithabu 1930-33, Nordelbingen 9,1934 , S. 341 ff.

Vilh. la C o u r: Det gamle Hedeby, Tilskueren 1933 I, S. $165-81$.

Resultaterne af Udgravningerne $i$ 1934 vil blive offentliggjort $i$ Nordelbingen 1935 af H. Jankuhn. 
en forbavsende Grad har den trodset Tiderne; kun mindre Partier af den er sløjfet, og Befæstningsarbejder i 1850 har ikke væsentlig ændret dens Præg. Dens Højde naar endnu paa sine Steder 10-11 m over det omgivende Jordsmon.

Halvkredsvolden er et Resultat af flere Slægtleds Arbejde. Dens Konstruktion er blevet oplyst ved Kielermuseets Under-

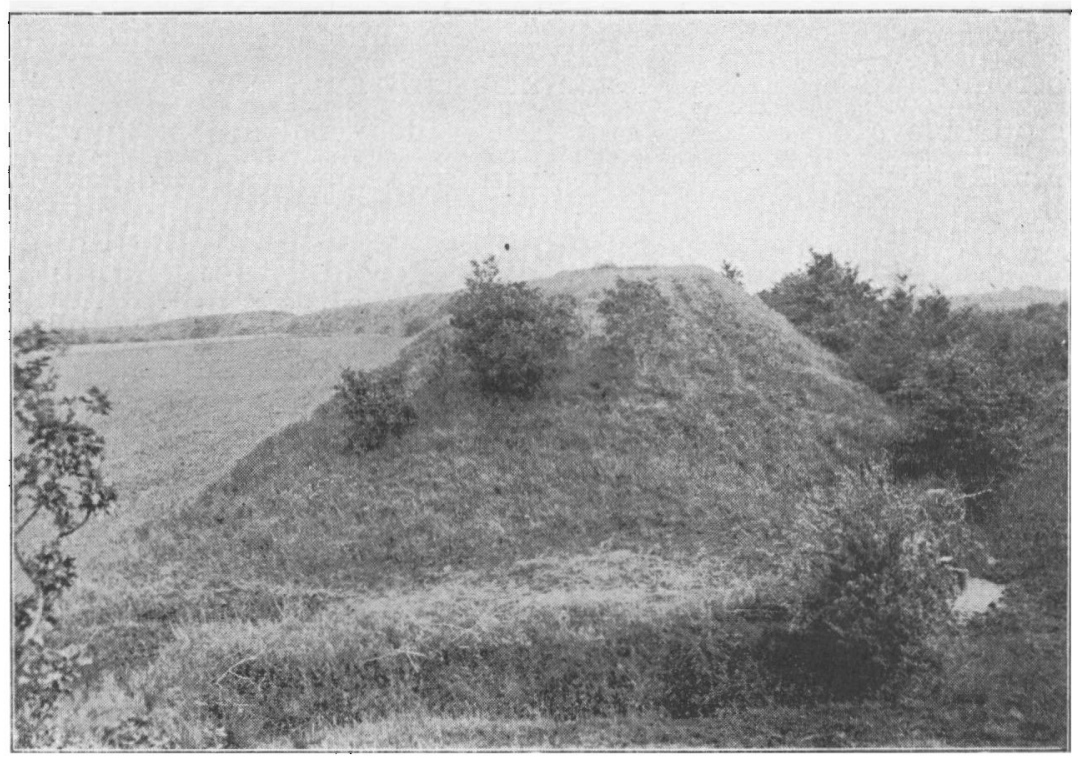

Fig. 3. Halvkredsvolden. Voldens sydlige Arm. Gennem Sankningen i Forgrunden loher en Bak ind over Byen.

I Mureum vorgeschicht. Altertumer, Kiel, tot.

sogelser, især i 1934, da der foretoges et Voldsnit i den nordlige Arm. Fra et lille Anlæg paa kun $2 \mathrm{~m}$ Højde er Volden langsomt - i Løbet af 8 Byggeperioder - vokset til en Højde af omtrent (6 $\mathrm{m}$. I Begyndelsen bestod Anlæget af en Vold med Palisadevægge, hvorover Jordmasserne hævede sig skraat til en Platform foroven; udadtil fortsæettes den ned efter i en spids Grav (Byggeperiode I). Senere beklædtes Volden med Græstørv, hvorved dens Front blev stejlere, men uden Træmur (Periode II -III). I de følgende Faser afstivedes Voldens Front atter med Palisader, samtidig med at dens Dimensioner blev større (Periode IV-VI). I den næste Fase skiftede Volden helt Karakter 
(Periode VII): Foran Volden dannedes en Afsats, der grænsede op til en henved $2 \mathrm{~m}$ dyb Grav med flad Bund. Samtidig forhøjedes den gamle Voldkrone, støttet af en Palisadefront. Paa denne Maade dannedes en dobbelt Forsvarslinje, der synes fastholdt $\mathrm{i}$ den sidste Byggeperiode (Periode VIII).

Denne Overgang fra en enkelt Vold med een Forsvarslinje til et kompliceret Anlæg med to eller flere Forsvarslinjer i Terrasser kan skyldes Impulser fra Samtidens stærkeste og berømteste Fæstning: Konstantinopels Bymur. Om dette Princip er blevet gennemført over hele Hedebyvolden eller kun i en Flankestilling ved Nordporten, kan først kommende Udgravninger oplyse. ${ }^{8}$ )

Kun paa tre Steder har denne Byvold levnet Adgang til Byen. Mod Vest, omtrent ved Voldens Midte, var Voldlinjen allerede i Oldtiden afbrudt, hvor en lille Bæk strømmede ind over Pladsen, som den delte i to Halvdele paa sin Vej mod Noret i Øst.

Ellers har der fra Landsiden kun været Adgang til Byen gennem to storre Porte, en i Nord- og en i Sydsiden af Byvolden. Ogsaa disse Portaabninger viser forskellige Byggeperioder. Over den ældste Vej af Træ, der har fort over den gamle Hedebund, som ogsaa Volden i dens ældste Parti er anlagt paa, er senere blevet lagt en stenbrolagt Vej, flankeret i Portaabningen af Tømmerkonstruktioner. ${ }^{9}$ )

Den store Halvkredsvold har ikke været det eneste Værn for Byen ved Noret. Fra Halvkredsvoldens vestligste Punkt udgaar mod Vest den godt $3 \mathrm{~km}$ lange F o r b in d e l s e s v o ld, der ved Danevirke Sø støder op til Danevirkes Hovedvold. Ligesom Halvkredsvolden er den blevet opført i flere Byggeperioder. Den

8) Beretn. orn Kn orrs Undersogelser ved Schwantes i Congressus II. Archæol. Rigæ 1930, $S$. 217 ff. En indgaaende Redegørelst" for Voldsnittet 19:34 vil fremkomme i 1. Bd. af "Die Ausgrabungen in Haithabu", ved $\mathbf{J}$ a $\mathrm{n} \mathrm{k}$ u $\mathrm{h} \mathbf{n}$.

*) Iflg. Knors Undersagelser. Jfr. Schwantes i Congressus Rigæ, S. 222. Muligvis har der varet en tredje Port, der har sat Byen i Forbindelse med Forvolden. Den har antagelig haft Plads mellem Vandløbet og Sydporten paa et Sted, hvor Voldlinjen endnu er afbrudt. 
ældste lave Vold har haft en Grav mod Syd, og ogsaa den har været forsynet med Palisader. Ikke mindre end to Gange er denne Vold blevet udvidet. $\left.{ }^{10}\right)$

Ca. $300 \mathrm{~m}$ fra Halvkredsvolden udgaar fra denne Forbindelsesvold en lav V o l d, der strækker sig parallelt med Halvkredsvoldens sydlige Arm mod Sø. Denne Vold, (mForvolden «) der ogsaa har haft Grav mod SV og været befæstet med Træværk, har været Byens yderste Front. ${ }^{11}$ )

Hele dette Voldsystem har gjort Byen ved Haddeby Nor til en af Nordeuropas stærkeste Fæstninger i Tiden omkring Aar 1000. Faa Hundrede Meter sydvest for Forvolden har staaet to Runestene fra Tiden omkring Aar 1000. Begge nævner de Navnet $\mathrm{Hedeby}$. Den ene er ifølge sin Indskrift rejst af Torlv, Svens Hirdmand, efter hans Fælle Styresmanden Erik "som døde, da tapre Mænd belejrede Hedeby“.'2) Den Fæs t n ing H e deby, som denne Sten omtaler, kan kun være identisk med Voldene omkring Bypladsen ved Haddeby Nor.

5. B y o m ra a et. Det Omraade, som Halvkredsvolden omslutter, har i Oldtiden, da Strandlinjen gik noget vestligere end i vore Dage, udgjort omkring 22 ha.

Hvor meget af dette vældige Areal har i Oldtiden været bebygget? Paa Forhaand var det sandsynligt, at Byens Vold af Forsvarshensyn var anlagt saa nær inde paa Bebyggelsen som muligt. $\left.{ }^{13}\right)$ Ved Anlæggelsen af den store Søgegrøft fra Volden til Noret 1930 viste det sig da ogsaa, at Bebyggelsen paa dette Sted havde strakt sig omtrent helt hen til Voldfoden, kun skilt fra denne ved en smal Passage. Ved Gennemførelsen af Søgegrøften i Retning mod Noret stødte man stadig paa Spor af Huse, undtagen paa en $200 \mathrm{~m}$ lang Strækning omtrent paa det Sted, hvor der i vore Dage gaar en Vej fra Nord til Syd over

10) Iflg. K n or rs Undersøgelser, meddelt af $\mathrm{S} c \mathrm{~h}$ wantes i Congressus Riga S. S. $219 \mathrm{f}$.

11) Congressus Rigæ S. 220. Tidligere opfattedes denne Vold som en Belejringsvold, opført af Sven $\mathrm{T}$ ve s kæg.

${ }_{12}$ ) Hedebystenen, jfr. W i m m e r: De danske Runemindesmærker, Haandudg. Nr. 72 (og 73).

13) Jfr. S chwantes i Congressus Rigæ S. 219. 
Pladsen. Her har der maaske i Oldtiden været en aaben Plads, men øst herfor har Bebyggelsen atter fortsat omtrent ned til Norets Bred. Hus har ligget ved Hus i omtrent samme Længderetning $(\mathrm{V}-\varnothing$ ell. SV-NØ), og flere Steder har man gentagne Gange bygget nye Huse paa gamle Hustomter. ${ }^{14}$ ) Endnu har Udstrækningen af de afidækkede Flader ikke været stor nok til, at man har kunnet erkende noget System i Bebyggelsen, - Gader og Stræder er endnu ikke paavist. ${ }^{15}$ )

Derimod har man kunnet udskille enkelte Kvarterer i Byen. Af Vandløbet er Byen blevet delt $i$ en nordlig og en sydlig Halvdel. I Nordøst, mellem Vandløbet og Noret, har man paa en lav Højning fundet Mængder af forarbejdet

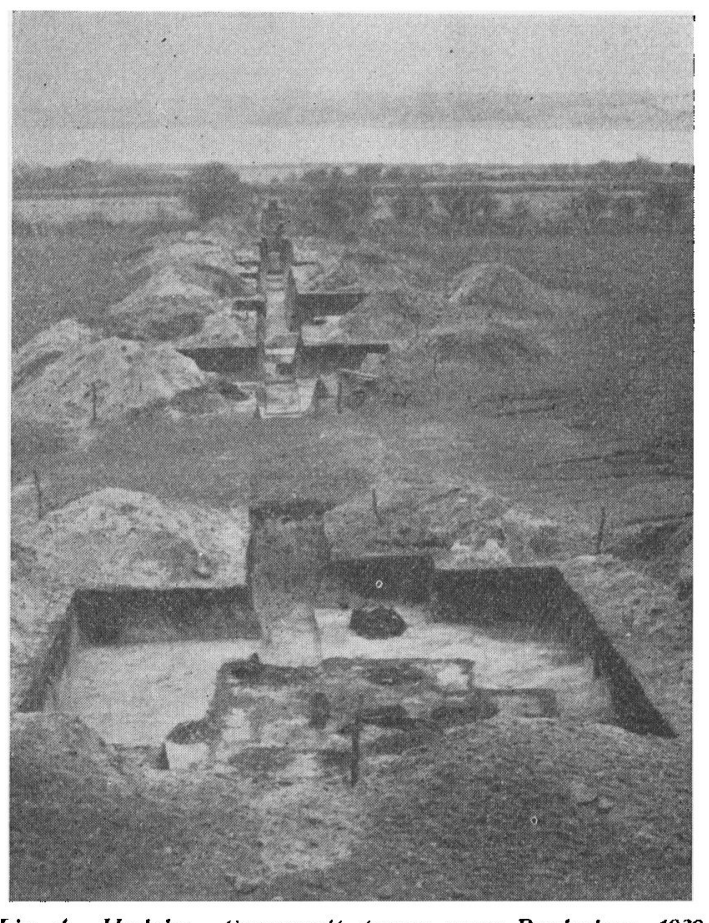

Fig. 4. Hedeby. Sogegrott tvars over Bypladsen 1930, set Ira Halvkredsvolden. I Forgrunden en Hustomt. I Baggrunden Haddeby Nor. /Musoum vorgeschlchtl. Altertumer fot. Hjortetak, Rester af en Glassmelteovn, Levninger fra Bronzestøberier og Sølvsmedeværksteder, især Støbeforme af Ler eller Vægsten; her har da Byens Haandværkere haft deres Værksteder - i dustrikvarteret $\left.{ }^{10}{ }^{16}\right)$

14) Især konstateret paa Bypladsens vestl. Dol. Jfr. l a C o u r s Bemerkninger om "Byplanen" i Tilskueren $1933 \mathrm{I}$, S. $170 \mathrm{ff}$.

15) Jfr. Ja n k u h n i Nordelbingen 9, S. $357 \mathrm{ff}$.

16) Jfr. K n o r r i Heimatbuch Schleswig I, 1924, S. 27. 
Syd for Vandløbet, i Vestenden af Byen, har de dode haft deres Kvarter. Her har man fremdraget Hundreder af Skeletter, - nær denne Byens $K$ i r k e g a a r d tor man vente at finde Tomten af en Kirke. Disse Grave mangler Gravgods og er uden Tvivl kristne. Syd herfor har der ligget Huse, men paa et Omraade, hvor der i 9. Aarhundrede havde ligget Kammergrave med hedensk Præg. Befolkningens Vækst har været saa stærk, at et Omraade, der i 9. Aarhundrede afsaas til Gravplads, i det 10. Aarhundrede maatte indtages til Bebyggelse. Den store Skeletgravplads er derimod forblevet urort; til denne Kirkegaard har man haft fredet Plads indenfor Byomraadet, saa lange Byen bestod. ${ }^{17}$ )

(i. Hus e ne. Allerede $\mathrm{K}$ n o r r havde ved sine Undersøgelser fundet Rester af Huse: Lerklining, forkullede Bjælker, Lergulve og Arnesteder - sammen med Levninger af deres Udstyr: knuste Lerkar, skaale af Vagsten, Vave- og Tenvægte m. m. ${ }^{14}$ )

Det var dog forst ved Undersogelserne fra 1930, at man fik nogen Klarhed over Husenes Konstruktion. I "den sorte Jord" er alle Tradele af Bygninger oplast og Husene derfor vanskelige at paavise. Men paa to Steder indenfor Bypladsen har Jordbundsforholdene været gunstige for Erkendelsen af Bygninger. Dels helt nede ved Noret, hvor Traet for en stor Del er bevaret paa Grund af den høje Vandstand, dels højere oppe paa Bypladsen, hvor vel alle Bygningsdele af organisk Substans er forgaaet, men hvor man dog $\mathrm{i}$ det lyse sand under "den sorte Jorl" kan se Trafundamenterne aftegnet som marke Humusstriber.

Nede ved Noret har man fundet Rester af et Hus, (II/32), hvis Vagge har bestaaet af tætstaaende, lodrette, nedgravede Planker. - Ikke langt herfira fandtes de forkullede Trærester fra et brændt Hus (I'32), hvor Vaggenes nederste Parti bestod af lorisontale Bræditer; indenfor disse var der med regelmassig Afstand rejst Stolper. Over Husets Indre laa spredt brændt Ler

17) Jfr. Schwantes i Jahrbuch der Schl-Holst. UniversitätsGesellschaft $1930,5.95$ ff.

is) Ileimatbuch Schleswig I, S. $27 \mathrm{f}$. 
fra Væggen. Disse Lerstumper havde en glat Side, der bar Aftryk af Tømmer, - dette Hus har da maaske haft en lerbeklædt Bræddevæg.

Mest oplysende var dog den første Hustomt, der blev fremdraget i 1930 (I/30). Tæt ved Volden saas i Sandet i $1 \mathrm{~m}$ Dybde tydeligt Omridsene af 3 Huse ( $\mathrm{a}, \mathrm{b}, \mathrm{c}$ ), der havde afløst hinanden paa samme Plet. Naar et gammelt Hus var brændt, byggedes et nyt paa dets Tomt, enten lidt storre eller lidt mindre, og maaske med lidt æudret Orientering, saadan at det er muligt at adskille Grundridsene af de forskellige Bygninger paa samme Plet fra hinanden. Det er i Hedeby meget almindeligt at finde 3-4 Husfundamenter over hinanden. Men da Beboerne i Tilfælde af Brand i Reglen har naaet at redde deres Ejendele, er det oftest ret vanskeligt at finde Holdepunkter for Bestemmelse af Bygningernes Alder. Ved Hus $I_{j} 30$ var dette imidlertid muligt.

Hus I c var en firkantet Rammebygning ( $4 \times 5 \mathrm{~m}$ ), med $\mathrm{Hj} ø \mathrm{r}-$ nestolper og Stolper ved Midten af Smalsideme. ${ }^{10}$ ) [ Sydøsthjørnet var det forsynet med en smal, firkantet Stensætıing, Husets Arne. Denne velbevarede Arne greb ind over den runde Arne og Sydøsthjørnet i Hus I b, der altsaa var ældre end Hus I c.

Hus I b var en lille Rammebygning $(3 \times 3,75 \mathrm{~m})$ uden Spor af Stolper. Dets Arne bestod af en rund Stenpakning i det sydostre Hjørne.

Medens Hus I b og c var parallelt bygget (SV-NØ), havde Hus I a en noget afvigende orientering $(\emptyset-V)$. Det var en lille Rammebygning $(2,8 \times 3,75 \mathrm{~m})$, hvis Østvæg var ødelagt ved Bygningen af Hus $I b$, der altsaa var yngre end Hus I a.

Saaledes var Husenes indbyrdes Aldersforskel bestemt. Men desuden var det muligt at give en omtrentlig Bestemmelse af deres absolute Alder. Ved Bygningen af Hus I $c$ er en Kvindegrav med 2 ornamenterede Spænder i "Osebergstil" (9. Aarh.)

10) la Cour formorler, at disse Stolper har stanct $\mathrm{j}$ Midten af Gavlvæggene og at de har stxttet Aashjalken - idlet Husene har haft Sadeltag. Tilskueren 1933 I, S. $176 \mathrm{ff}$. 
blevet forstyrret. Indenfor Huskonturerne fandtes en Bronzedupsko ornamenteret $i$ »Borrestil« (10, Aarh.), - men det var umuligt at sige, hvilket af de 3 Huse den hørte til. Desuclen fandtes i dette Huskompleks 2 Møllestene af rhinsk Basaltlava, - for tunge at flytte under en pludselig Brand.

Den simple Hustype, som fremtræder i Hus I/30, ser ud til at have været almindelig i Hedeby. Boligerne er smaa firkan-

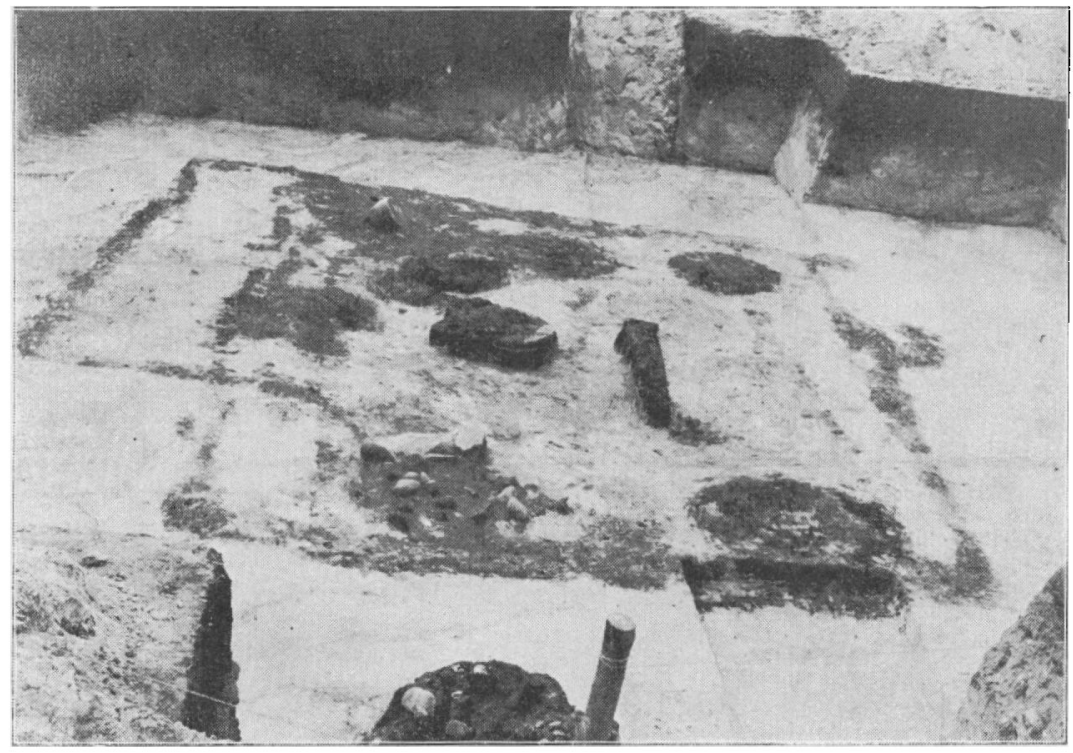

Fig. 5. Hedeby. Hustomt. Paa Billedet ses Omridsene af 3 Huse (I/30). der har aflost hinanden paa samme Plet. I 7 omten ses et Arnesled og flere Gruber. I Midten ses en Mollesteh at rhinsk Basalttava. / Museum vorgeschichti. Altertumor fot.

tede Bygninger, fundamenteret paa vandret lagte Bjælker. Paa denne Tømmersyld har Vægstolpen hvilet, der har støttet Vægge af Greneværk og Ler. Husene i Hedeby har enten været af Bindingsvark eller helt af Træ. Af Tage og Døre er intet bevaret. Kun $i$ et enkelt Hus er der fundet Spor af Gulvbrædder.

I 1933 fandt man $i$ et Hus (I/33) under den nederste vandrette $B j æ l k e$ et rundt Lerkar indsat $i$ en Fordybning - vel som et Byggeoffer.

A r n e n, en rund eller firkantet Stenpakning lagt i Ler, ha: 
næsten altid haft Plads i et Hjørne af Huset, kun sjældent $i$ dets Midte.

Foruden Arnen rummer Husene hyppigt en eller flere kredsrunde $\mathrm{Gr}$ u b r med mork Fyld, der rummer forraadnende vegetabilske eller animalske Stoffer, Knogler, Lerkarskaar, Slagger, Aske og itubrudte Redskaber. De fleste af Gruberne har været Affaldsgruber, - andre synes at have tjent som Forraadsgruber. ${ }^{20}$ )

Huse af samme beskedne Karakter som Hedebys er i de senere Aar fremdraget paa flere Bopladser fra Tiden kort efter Aar 1000: I Brovold paa Als, i Sigtuna i Sverige, i Oppeln i Østpreussen. ${ }^{21}$ )

7. Brøndene. Hedeby forsynedes med Drikkevand fra store Brønde, der laa i Nærheden af Boligerne. Flere Brønde er blevet udgravet paa Bypladsen; én - fra de ældre Gravninger - staar opstillet i Museet i Kiel; ved de senere Udgravninger er der blevet fremdraget Brønde i 1930, 1931 og flere i 1933.

Deres Konstruktion er ret ensartet. Forst er der gravet en Grube, foroven ca. $3,5 \mathrm{~m}$ i Gennemsnit og ca. $4 \mathrm{~m}$ dyb. Fra Bunden af denne Grube er der fort en firkantet Skakt ned i de vandførende Lag. I Skaktens fire Hjørner var nedrammet Træpæle, der fastholdt en Træramme, bestaaende af horisontale Planker. I den Brønd, man fandt 1931, havde man inden $i$ denne Skakt nedrammet en Række lodrette Pæle og indenfor dem nedsænket endnu en firsidet Ramme, fastholdt af fire Stolper. Den derved dannede firkantede Træskakt fortsattes derefter opadtil med en snævrere Træskakt - maaske en udhulet Træstamme - hvorefter den store Grube atter tilkastedes.

Ved Brøndanlæg af denne Art havde Byens Indbyggere sikret sig rent og rigeligt Drikkevand. ${ }^{22}$ )

8. Grave ne. Hedeby har haft to Gravpladser af vidt forskellig Karakter.

20) Om Udgravning af IIuse efter 19:30 se la Cour i Tilskueren 19333 I. S. 176 ff., J a $n \mathrm{k}$ u $n$ i Nordelbingen S. $344 \mathrm{ff}$.

21) Jfr. J a $n \mathrm{k}$ u h $\mathrm{n}$ i Nordelbingon 2, $\mathrm{s}$. $363 \mathrm{ff}$.

$\left.{ }^{22}\right)$ Om Brondene se I a Co u r i Tilskueren 19:33 I, S. $180 \mathrm{f}$, J a n$\mathrm{k} u \mathrm{~h} n \mathrm{i}$ Nordelbingen 9 , $\$$. $355 \mathrm{ff}$. 
Indenfor det tat bebyggede Omraade $i$ Sydvest har man i de senere Aar fremdraget en halv Snes "K a $\mathrm{m} \mathrm{m}$ e r g r a ve«, d. v. s. smaa tømrede Gravkamre, hvis Storrelse veksler mellem 1,5 $\times 2,5$ og 2,4 $\times 3,0 \mathrm{~m}$. I et enkelt Tilfælde var en saadan Kammergrav ved en Skillevæg delt $i$ et nordligt og et sydligt Kammer (Kgr. III/30). I Kammergravene er de døde efter hedensk

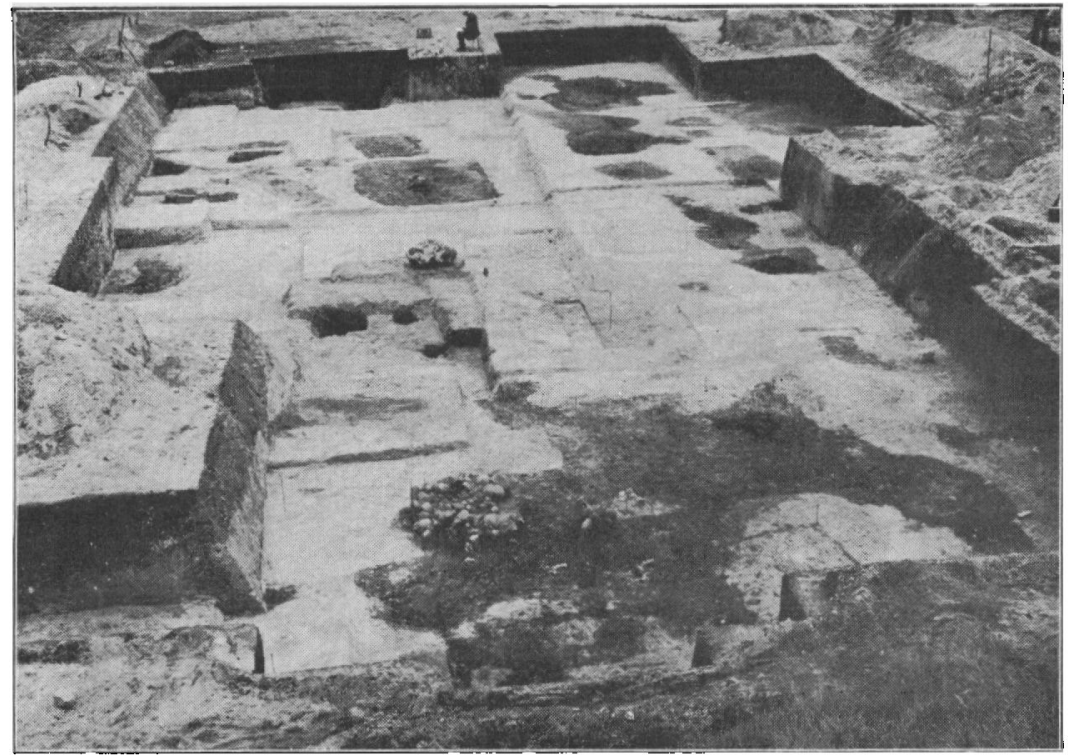

Fig. 6. Hedeby. Aldokket Felt med morke Pletter af Kulturjord paa gul Undergrund. 7. v. i Baggrunden en Hustomt, t. H. i Baggrunden Spor af Kammergrave og Gruber; $i$ Forgrunden en Arne.

Skik gravlagt med rigt Udstyr. Blandt de fremdragne Grave var der kun een sikker Kvindegrav (Dobbeltgraven III/30). Den indeholdt to skaalformede Spænder, et ovalt, forgyldt Bronzebeslag, en Kæde af Bjergkrystal- og Karneolperler og en Bronzeknap med Ravindlægning. - Mandsgravene indeholdt især Vaaben: Spydspidser, Skjoldbuler, en enkelt Gang en Dolk, men ogsaa andre Kostbarheder som f. Eks. et Træskrin, en Bronzeskaal, en bronzebeslaaet Træspand (Kgr. I/30). I tre af disse Kammergrave (1931) er fundet Efterligninger af Mønter, som Karl den Store omkring 800 lod præge i Dorestad. Efterlignin- 
gerne er udført i første Halvdel af 9. Aarhundrede. Ogsaa Skaalspænderne i Kvindegraven maa snarest henføres til 9. Aarhundrede, medens den store Træspand har Sidestykke i to Fund fra 10. Aarhundrede (Stengade paa Langeland, Wiskiauten i Østpreussen). De hidtil afdækkede Kammergrave er dog for det meste saa gamle, at de er delvis odelagt ved Anlæg af Huse og af større eller mindre Gruber. ${ }^{23}$ )

Kammergraven er en Gravform, der kan forfølges syd- og vestpaa til Westfalen. Den gaar tilbage til senromerske Forbilleder. I Danmark er den sjælden, men i Birka i Sverige er Kammergrave af samme Karakter som Hedebys almindelige. ${ }^{24}$ )

Af helt anden Karakter var de Grave, der udgravedes paa Hedebys storste Gravplads. Syd for Vandløbet, paa Bypladsens vestlige Del, paavistes allerede ved de ældre Gravninger en stor Skeletgravplads, ca. $50 \times 120 \mathrm{~m}$ i Omfang. Et Par Hundrede Grave er undersøgt her. Ligene ligger tæt, i forskellige Lag over hinanden, alle med Hovedet i Vest; de er i Reglen begravet i Trækister, hvoraf kun Nagler og Beslag nu er tilbage, og de er kun sjældent udstyret med Gravgods. Paa Gravpladsens midterste og østlige Del stødte man dog paa rige Kvindegrave, hvori fandtes Kæder af Bjergkrystal og Halvædelsten og Smykker af forgyldt Bronze og af Sølv.".") De Grave, der i de senere Aar er undersøgt paa Gravpladsen, har atter været fattige paa Gravgods. Som Helhed har da denne Gravplads en kristen Kirkegaards Karakter.

Kun een Brandgrav er paavist i Hedeby, - den laa mellem to Kammergrave, men da den ikke indeholdt Gravgods, var Tidsbestemmelse umulig. ${ }^{26}$ )

Den prægtigste af alle Hedebys Grave var Ba a d kammergraven. I 1908 fandtes mellem Halvkredsvolden og Forvolden en dobbelt Kammergrav. Over Kamret saas Naglerne fra en 16-20 $\mathrm{m}$ lang Baad, der havde været anbragt oven over

${ }^{23}$ ) Om Kammergravene se Sch wantes i Zeitschr. f. Ethnologie 1931, S. 243 ff., Ja $\mathrm{n} \mathrm{k}$ h $\mathrm{n}$ i Nordelbingen 9, S. $352 \mathrm{ff}$.

24) Jfr. T. J.: Arne i Acta Archaeologica II 1931, S. 301.

25) $\mathrm{K}$ n or $\mathbf{r}$ i Heimatbuch Schleswig I. S. 28 .

26) J a $\mathrm{n} \mathrm{u}$ h $\mathrm{n}$ i Nordelbingen 9 , S. 355 . 
Kamret, støttet af store Sten. Over Baaden havde man hvælvet en lav Høj. I Kamrets to Rum fandtes Ligene af to Krigere med deres Heste og et fyrsteligt Udstyr: Sværd med sølvindlagte Hjalter, hængende $i$ et sølvbeslaaet Bælte, - Skjolde, Pilekoggere, Ridetøj, Træskrin og Træspand, Bronzeskaal og Glasbæger $\mathrm{m}$. m. Denne Grav maa henføres til Begyndelsen af det 10. Aarhundrede. Baadkammergraven i Hedeby er den eneste paa gammel dansk Grund; demne Gravform er derimod kendt i Norge og udbredt i Sverige; fra Birka kendes en Kammergrav, der i Form og Udstyr minder slaaende om Baadkammergraven fra Hedeby. ${ }^{27}$ )

Baadkammergraven vidner om stærk svensk Indflydelse i Hedeby i 10. Aarhundrede; endnu et Gravminde fra Hedeby bæerer svensk Præg. To Runestene, der er fundet tæt ved Hedeby, Vedelspangstenene, begge fra 10 . Aarh.. bærer den omtrent ligelydende Indskrift, at A s f rid, Odink a r s Datter, gjorde dette Mindesmærke efter Sig t ry g Konge, hendes og G n u pas Søn, paa Gnupa $s \mathrm{~V}$ i. Den ene af disse Indskrifter har udpræget svenske Rune- og Sprogformer og er sandsynligvis ristet af en svensk Runemester. ${ }^{28}$ ) I en tysk Kilde fra Slutningen af 10. Aarh., W i d u k i n d s Sakserkrønike, omtales C h n u ba som Danernes Konge, der $\mathrm{i} 934$ besejredes og tvangsdøbtes af den tyske Konge He n rik $I^{29}$ ) En Konge, Gnupa, har altsaa i 10. Aarhunlrede haft sit $" V i \ll$, sit indviede Gravsted, nær Hedeby.

9. Hedebys Ind ustri. De Tusinder af Redskaber, Vaaben og Smykker, der er fremdraget paa Hedebys Grund, er for en stor Del lavet i Byen selv.

Det gælder først og fremmest en stor Del af Lerkarrene, men Pot te mageriet har ikke staaet højt i Hedeby. Dets Produkter er især smaa kugleformede Kar af simpel Form og slet Udførelse. Saadanne Kuglepotter er i Tiden kort før Aar

$\left.{ }^{27}\right)$ Fr. K n o r r: Bootkammergrab südlich der Oldenburg. Mittheilungen d. anthrop. Vereins in Schl.-Holst. 19, 1911, S. $68 \mathrm{ff}$. Jfr. I a Ci o u rs illustr. Beskrivelse i Sanderjyll. Hist. I, S. $258 \mathrm{ff}$.

${ }^{28}$ ) W i m me r: De danske Runemindesmærker, Haandudg. Nr. 70 (og 71 ).

${ }^{20}$ ) Kildestedet aftrykt i S c h e e l u. P a u l s e n: Quellen zur Frage Schleswig-Haithabu, S. 80. 
1000 blevet lavet over hele Norden og langt ned i Tyskland. Medens disse Potter er helt haandgjorte, findes ved Siden af dem ogsaa helt eller delvis drejede Kar. Særlig mærkelige er nogle Skaale, der er formet som Pokaler - men med et Hul i Foden som til at anbringe paa en Tap; maaske har de været anvendt som Lamper. Af Ler har man desuden lavet Tensten og Vævevægte. Ved Siden af disse hjemmelavede Varer optræder importerede Lervarer af højere Kvalitet.

En større Rolle har Knogletilvirkningen spillet. Af Knogler af Hjorte og Elsdyr har man forstaaet af lave en Mængde Smaating til Tilfredsstillelse af Dagliglivets Behov: Knive, Spindesten, Naale og Prene med eller uden Øre, men især Kamme. Kammageriet har været en Specialitet i Hedeby, - efter Tidens Vilkaar har der været en formelig Masseproduktion deraf; man har fundet Kamme paa alle Forarbejdelsens Stadier. Ogsaa Skøjter tilvirket af Knogler har man fundet $i$ Hedeby. I et af de Huse, der er fremdraget $i$ de senere Aar (II/30) fandtes en saadan Mængde af forarbejdede Hjortetakker, at man i dette Hus vel tør se en Kammagers Værksted. Kun i den lavtliggende, fugtige Jordbund tæt ved Noret har man fundet bevarede $\mathrm{T} \mathbf{r} æ \mathbf{s} \mathrm{ag}$ e $\mathrm{r}$ (f. Eks. en drejet Tallerken og en Øseske), men af fremtidige Undersøgelser tor man her vente et større Udbytte. Hvor mange af disse Træsager og af de talrige J e r n s a e r (Segle, Knive, Økser, Nøgler - og egentlige Vaaben), der er tildannet i Hedeby selv, kan ikke afgøres.

Der har dog i Hedeby været drevet Met a l ha a ndvær k i stor Stil. I "Industrikvarteret" har man fundet Efterladenskaber fra Bronzest b bernes Værksteder: Støbeforme af Ler eller Vægsten til trefligede og ovale Bronzespænder, dels med Ornamentik i karolingisk Bladstil fra 9. Aarhundrede, dels med udpræget nordisk Dyreornamentik; Smeltedigler, hvori det i Barrer indførte Raastof indsmeltedes; desuden Hamre, smaa Ambolte, Tænger, Vægte og Lodder. Ved Siden af Bronzestaberne har der været $\mathrm{S} ø \mathrm{lvs}$ mede. Foruden Støbeforme af Vægsten til Sølvbarrer har man fundet en Støbeform af samme Materiale til en Thorshammer. Endelig har der været $\mathrm{V}$ a a- 
be nsmede; som Levning fra Vaabenfabrikation er fundet en Støbeform til en Parérstang paa et Sværd.

Saa forgrenet var Kunstindustrien i Hedeby, at der var Plads til et Glasværk. Herom skriver Knorr: "Ved den østlige Rand af den svage Højning nord for Vandløbet fandtes et Arnested med stærke Brandspor, tæt herved mange Rester af itubrudt og smeltet Glas, færdige og ituslaaede Perler, færdige Glaspaster med smuk Ornamentering og især stavformede Glaspaster, der har tjent til Sammensætning af farvede Glasarbejder". I dette Værksted for Glasarbejder er sikkert mange af de skøntfarvede Perler, der er fundet rundt om paa Bypladsen, blevet fremstillet. ${ }^{30}$ )

10. Hedebys Handel. Den Industri, som i 9. og 10. Aarhundrede blomstrede i Hedeby, var betinget af let Adgang til Raastoffer og af et stort Afsæetningsmarked.

Hedeby havde let Adgang til Raastoffer i Kraft af sin Beliggenhed ved en af Tidens vigtigste Handelsveje. Af Fundene fremgaar, at Hedeby forst og fremmest var en Handelsby. Dens Handel har for en stor Del været i Hænderne paa professionelle Købmænd ${ }^{31}$ ) og været forbundet med en b e g y nde nde P e nge o $\mathrm{ms} \mathrm{s} \mathrm{n}$ ing. Man har paa Hedebys Grund fundet en hel Del Mønter: karolingiske, byzantinske, arabiske, ottonske. Efterligninger af Karl den Stores Dorestadmønter ser ud til at være præget i selve Hedeby fra Begyndelsen af 9. Aarhundrede. Ved Siden af Mønter har $\mathrm{S} ø \mathrm{l} \mathrm{v}$ b a r r e r, hvortil man har fundet Støbeforme i Hedeby selv, tjent som Omsætningsmidler. Disse Sølvbarrer, hele eller sønderhuggede, er blevet vejet paa Vægte; man har i Hedeby fundet $\mathrm{V} æ \mathrm{~g}$ t e af Jern med tilhørende Lodder, der ogsaa var af Jern men overtrukket med Bronze, for at man ikke skulde forringe Vægten ved at kradse i Jernet. ${ }^{32}$ )

$\left.{ }^{30}\right)$ Kendskabet til Hedebys "Industri" skyldes især $\mathbf{K}$ n o r r s Gravninger, jfr. Oversigten i Heimatbuch Schleswig S. 27. Endvidere: Schwantes i Zeitschr. f. Ethnologie 1931, S. $242 \mathrm{f}$., og for de seneste Aar: J a n k u h n i Nordelbingen 9, S. 359 ff. I Ipek vil i nær Fremtid komme en Afhandl. af Jankuhn: "Das Kunstgewerbe in IIaithabu".

$\left.{ }^{31}\right)$ Jfr. de skriftlige Kilders Vidnesbyrd, se nedenfor Kap. 11.

32) Jfr, S chw an tes i Kieler neueste Nachrichten 1.-2. ()kt. 1930. 
Hvor let en Sag det var ad Handelsvejen at skaffe Varer til Byen fremgaar deraf, at en stor Mængde af de L e r k a $r$ der er fundet i Hedeby, er importerede Varer. I stor Mængde optræder de saakaldte $\mathrm{P}$ ing $\mathrm{s}$ d or f-Kar, Lerkar med rød- eller brunmalede Pletter, der især fremstilledes i Egnen omkring Køln, hvor Landsbyen Pingsdorf ligger; ved Siden af dem forekommer lyse Kar med frankisk Stempelornamentik, fremstillet i Rhinegnene (især v. $\mathrm{B}$ a d or $\mathrm{f}$ i Nærheden af Pingsdorf) fra tidlig karolingisk Tid; af dem har nogle store Amforaer, der bærer Lister med tandhjulformede Indstemplinger, sandsynligvis været brugt til Vindunke; endelig findes ret hyppigt $\mathrm{K}$ a $r$ m e d B øl g e l i n j e r som Ornamenter, en Vare, der fuldstændig svarer til de østholstenske og sl a visk e Bopladsers hjemlige Keramik. - Endelig er der fra Rhinegnenes Basalt- og Tufstensbrud importeret Møllesten i Mængde. ${ }^{33}$ ).

Selv hvor Fundene ikke viser Nedslag af direkte Import, gør stærk Paavirkning udefra sig gældende. Især er $f$ ran$\mathbf{k} \mathbf{i} \mathbf{k}$ I $\mathbf{n}$ d f l ly de l s e fremherskende. Ofte viser Støbeformene til trefligede og ovale Spænder karolingiske Motiver: bl. a. Akanthusornamentik. De karolingiske Motiver er i Hedeby blevet omformet. Spænder, hvortil man har fundet Støbeforme i Hedeby, forekommer spredt over hele Norden, især i Østersøomraadet. I Handelens Spor er gaaet en stærk kulturel Indflydelse i det hele; nye religiøse Strømninger er fra 9. Aarhundrede at Handelsvejen trængt frem til Hedeby.

Fundene fra Hedeby viduer tillige om en stærk Handelsforbindelse med den skandinaviske Halvo. Fra Norge er importeret Vægsten, anvendt til Skaale og Støbeforme. I Hedeby har man fundet Støbeforme til ovale Spænder af Berdaltypen, der $\mathbf{i}$ 9. Aarhundrede har været stærkt udbredt i Norge omkring Sogn og Fjordene, men ellers kun forekommer i Birka og Hedeby.

Fra 10. Aarhundrede har man i Hedeby fundet Støbeforme til barokke, gennembrudte ovale Spænder, der er udbredt $i$

33) Jfr. Schwantes i Congressus Rigæ, S. 223 f., Zeitschrift f. Ethnologie 1931, S. 242 f. Importkeramiken fra Hedeby vil blive indgaaende behandlet af $J$ a $\mathrm{nuhn}$ i I. Bind af "Die Ausgrabungen ip Haithabu«. 
Sverige $\left.{ }^{34}\right)$. I det samme Aarhundrede har svensk Indslag i Hedeby sat sig Spor i Baadkammergravell og i Vedelspangstenens Rune- og Sprogformer.

11. De litterære Kilder til SlesviguHedebys H is tori e. De arkæologiske Undersøgelser ved Haddeby Nor - fra 1900 til i Dag — har godtgjort Eksistensen af et Bysamfund her omkring ved Oldtidens Slutning. De ældste Fund, der er gjort paa Stedet, er Fundene i tre Kammergrave af Efterligninger af Dorestadmønter (1931); disse Efterligninger maa henføres til Begyndelsen eller i hvert Fald første Halvdel af det 9. Aarhundrede. Den store Masse af Fund, der kan dateres, maa henføres til 10. Aarhundrede. De yngste Fund paa Pladsen er af tyske Mønter fra 1. Halvdel af 11. Aarhundrede og af et Lukasemblem af Bly eller Tin (11.-12. Aarh.), fundet i Nærheden af Skeletgravpladsen $\left.(1930)^{35}\right)$.

En stor By har da ligget ved Haddeby Nor, tæt ved Slien, i det 9., 10. og Begyndelsen af det 11. Aarhundrede. Det staar tilbage at undersøge, hvad samtlige litterære Kilder kan give af Oplysning om denne By, dens Navn og dens Skæbne. ${ }^{36}$ )

Første Gang, en By ved Slien omtales i Litteraturen, er ved Aaret 804, da de omtrent samtidige f r a n k is ke Rig s a n n al er meddeler, at Danernes Konge God fred kom med sin Flaade og hele sit Riges Rytteri stil det Sted, som hedder Slies th or p, paa Grænsen mellem hans Rige og Saksland" for at forhandle med Kejser $\mathrm{K}$ a rl de $\mathrm{n} \mathrm{St} \mathrm{or} \mathrm{e.}{ }^{37}$ ) Ved Aaret 808, meddeler Annalerne, angreb Godfred de slaviske Obotriter; efter at have ødelagt deres Handelsplads Reric ved Østersøkysten; tog han deres Købmænd med sig og sejlede med sin Flaade "til den Havn, som hedder Sliestorp«. "Her var det, at Godfred beslut-

34) Om de ovale Spænder se P. P a uls en: Studien zur Wikingerkultur, 1933, især S. 31 ff.

$\left.{ }^{35}\right)$ Om Mønterne: S c h w an tes i Kieler neueste Nachrichten 4/11. 1931. Om Lukasemblem: J a n k u h n i Nordelbingen 9, S. 362.

36) Alle Kildesteder vedrørende Spørgsmaalet Slesvig-Hedeby findes aftrykt med Henvisninger i Samlingen: Quellen zur Frage Schleswig-Haithabu, udg. af Ot to S ch e e l og P. P a u l s e n, 1930 (i det flg. betcgnet: Quellen).

i7) Quellen S. 24. 
tede at befæste sit Riges Grænse mod Saksland med en Vold fra Østersalt til Vesterhavet. ${ }^{88}$ )

Hvor dette Sliestorp har ligget, og hvor Godfreds Vold har gaaet, besidder vi ingen Midler til at afgøre. Kildestedet viser kun, at Handelsveje allerede omkring ved 800 har krydset det vestlige Østersøbækken og dannet Basis for en merkantilistisk aggressiv Politik fra den Konges Side, der besad Herredommet ved Slien.

Anden Gang omtales en By ved Slien, da R i mbert i "Ansgars Levned", forfattet kort efter Ansgars Død 864, beretter, at Kong $\mathrm{H}$ ori $\mathrm{k}$ tillod Ansgar at bygge en Kirke "i den Havn i hans Rige .... som hedder Sli a s w i c h«, hvor Købmænd traf sammen fra alle Sider. Dér fandtes nemlig i Forvejen mange kristne, som havde modtaget Daaben enten i Dorestad eller i Hamburg - og blandt dem de mest ansete i Byen. Glæden over denne Kirkes Opførelse var efter Rimberts Udsagn saa stor, "at ogsaa vore Landsmænd uden Frygt - hvad der tidligere ikke var muligt - og Købmænd baade herfra (nemlig fra Hamburg) og fra Dorestad nu drog til dette Sted, og herved opstod der Overflod paa alt ${ }^{38}{ }^{39}$ )

Første Gang, S l e s vig nævnes i Litteraturen, er det da som en livlig Handelsby med stærke Forbindelser med Hamburg og Dorestad; i dens Befolkning har der udskilt sig en lille kristen Overklasse, der utvivlsomt er faldet sammen med et Kobmandsaristokrati. - Om Byens Beliggenhed siger Rimbert intet. Ansgars Sliaswich har dog næppe ligget, hvor Slesvig nu ligger, da der her intet er fundet fra 9. Aarhundrede; ${ }^{* 0}$ ) det er derimod Tilfældet ved Haddeby Nor, - her har der i 9. Aarhundrede ligget en Havneby, og her er fremdraget Fund, der vidner on frankiske Handelsforbindelser og lang Tids kristen Paavirkning.

Slesvigs Ry er naaet helt til den arabiske Kulturverden. I en a rabisk Rejseskildring fra 10. Aarhundrede omtales en spansk Arabers, A t-Tart ûschîs Besøg i Schleswig

$\left.{ }^{3 *}\right)$ Quellen S. 25.

39) Quellen S. $69 \mathrm{f}$.

10) Jfr. S ch wa n te s i Zeitschr. f. Ethnologie 1931, S. 249. 
ved Midten af 10. Aarhundrede. Slesvig er, selv efter hans Opfattelse, "en meget stor By ved Oceanets yderste Rand«. Men dens Kultur har frastødt Araberen: "Dens Indbyggere er Tilbedere af Sirius, bortset fra et lille Antal, som er kristne og har en Kirke. De fejrer en Fest, hvorved de alle kommer sammen for at ære Gud og spise og drikke. Den, der slagter et Offerdyr, rejser for sit Hus Pæle og hænger Offerdyret op derpaa, hvad enten det er en Okse eller en Væedder, en Gedebuk eller et Svin, for at Folk kan vide, at hal ofrer det til Are for sin Gud. Byen er fattig, dens Beboeres Hovedernæring er Fisk, hvoraf de har Masser. Nyfødte Børn kastes i Havet for at spare Omkostningerne ved deres Opfodelse; Kvinden har Ret til at forlange Skilsmisse, naar hun vil. Aldrig har jeg hørt en hæsligere Sang end Slesvigernes; den ligner Hundegøen.«")

Hvis Araberens Indtryk er rigtigt, har det ikke staaet for godt til med Kristendommen hundrede Aar efter Ansgars Mission. Hans Hovedindtryk af Slesvig er, at den sin Størrelse til Trods er en fattig og uciviliseret $\mathrm{By}$.

Der er andre Efterretuinger om Byen ved Slien end disse, men her kaldes den $\mathrm{H}$ e d e b y.

Da Kong Alfred den Store af England omkring 890 . udgav en Oversættelse af Orosi us' latinske Verdenshistorie, knyttede han hertil et Par Beretninger om ohteres og W u l f stan s Rejser.

O h t e re var en norsk Høvding (Ottar!), der havde hentet Pelsvark helt oppe ved det hvide Hav; fra Haalogaland sejlede han med det ned til Skiringssal, den store Markedsplads i Vestfold, og derfra i fem Dage videre til den Havn, som man kalder »æ $\mathrm{t} H æ t \mathrm{~h} u \mathrm{~m}$ «, — »den ligger mellem Vender og Sachser og Angel og hører under Danerme«. Paa Rejsens to sidste Dage havde han til Bagbord de Øer, der hører til Danmark; til Styrbord havde han Gotland, Sillende og mange Øer, - i disse Lande boede Anglerne, for de kom til Britannien. - Ottars Rute er gaaet gennem Lillebælt til Havnen "ved Hederne".

") Quellen S. 130. (Oversat i A r u s Danmarks Historie I, S. 121. 
Den samme Havn var Udgangspunktet for W u lf st a in s Rejse i Østersøen. Paa syv Degn sejlede han herfra til Truso (vistnok ved Weichsels Udløb, i Nærheden af Elbing). Under denne Fart havde han til Styrbord Vendland, til Bagbord Langeland, Laaland, Falster og Skaane, hvilke Lande alle hører til Danmark, derefter Burgendaland (Bornholm), der har en egen Konge, derefter Bleking, Møre, øland og Gotland, der hører til Svenskerne. ${ }^{42}$ )

Den Havn, som var Maalet for Ottars Rejse og Udgangspunktet for Wulfstans, kaldes her kun "ve d H ed e r n e«. Saasnart der omkring Havnen "ved Hederne" var opstaaet en fast Bebyggelse, laa det nær at ændre Navnet til $\mathrm{H}$ e d e b y: Bebyggelsen ved Hederne. Saaledes kaldes Byen paa tre Runestene fra Tiden omkring Aar 1000. ${ }^{43}$ )

En tysk og en arabisk Skildring fra 9.-10. Aarhundrede omtaler altsaa en By ved Slien, der hedder Sl esvig, en angelsaksisk fra omkring 900 omtaler en Havn ved Slien, der hedder "æet Hæthum", og nordiske Runestene fra omkring Aar 1000 taler om $\mathrm{H}$ e d e b y. Har der da ved Slien ligget to Byer, Slesvig og Hedeby, eller er det to Navne paa een og samme By? Det vilde være mærkeligt, om der paa denne Tid, da Byer knap fandtes i Skandinavien, skulde have ligget to Byer, hvoraf een meget betydelig, klods op ad hinanden, og Litteraturen omtaler da heller ikke, at der har været mere end een By. Fra det nuværende Slesvigs Omraade er der ingen Levninger fremdraget, der kan føres tilbage til denne Tid, - medens der bag Halvkredsvolden er fremdraget Levninger af ell stor By, der kan henfores til det 9. Aarhundrede og har blomstret i det 10. Aarhundrede. Dette tyder paa, at Slesvig og Hedeby er forskellige $\mathrm{Navne}$ pa a same By, en Opfattelse, tler,

12) Quellen S. 129.

43) Hedebystenen: hitha $X$ bu, W i m m e s Haandudg. Nr. 72 ; Danevirkestenen: hitha: bu, Nr. 73; Aarhusstenen I: hithabu, Nr. 2R. Det er efter Hedebystenen, at Tyskerne har optaget den noget skurrencle Betegnelse $\mathrm{Ha}$ i th a bu for Omraadet bag Halvkredsvolden. 
forst fremsat af den svenske Arkæolog $K$ n $u$ t $S$ j e r n a, har vundet stadig større Tilslutning. ${ }^{4}$ )

Denne Opfattelse var i Virkeligheden allerede Samtidens. I den angelske Krønike, der kort før Aar 1000 er forfattet af Jarl Ethelwerd, en Atling af Kong Alfreds Broder E t h e l r e d, staar der om det gamle Angels Hovedstad, at d e n i det sachsiske Sprog hedder Sleswic, men hos Da n er n e H a i th a b y."i) Saaledes forholder det sig virkeligt, - i sachsiske Beretninger tales altid om slesvig, i de æoldre nordiske Kilder altid om .Hedeby.

Den sanıme Opfattelse møder vi hos A a m a f B rem en i 1070'erne. I sit Værk, "De hamburgske .Erkebispers Historie«, nævner han ofte "sliaswig, som ogsa k aldes Heidiba; udførligt onitaler han Byen under sin Beskrivelse af Danmark, hvor han siger, at den "beskylles af en Arm af det barbariske Stræde, som Indbyggerne kalder Slien, hvoraf ogsaa Byen har sit Navn«. "Fra dens Havn« - siger han videre "afsejler ofte Skibe til Vendland, til Sverige, til Samland, ja lige til Grækenland."

12. Slesvig-Hedebys Plads i Nordeuropas Ha $\mathrm{n}$ d e $1 \mathrm{~s} l \mathrm{i}$.

Saavel de arkæologiske Undersogelser ved Haddeby Nor som de litterære Kilder om Bysamfund ved Slien viser, at Slesvig-Hedeby har haft en betydningsfuld Plads i nordeuropæisk Handelsliv i 9.-11. Aarhundrede.

44) Knut S t je rna: Lund och Birka. Hist. Tidskr. f. Skåneland 1909 , $\mathrm{S}$. $171 \mathrm{ff}$. (Som Parallel anfører Stjerna det niddelalderlige Malmø, der af udenlandske Kobmæend kaldtes Ellenbogen). Til StjernasAnskuelse har den svenske Forsker E I i a tyske Forskere otto Scheel, G. Schwantes og H. Jankuhn sluttet sig, medens den danske Forsker Vilh. la C o u r stadig fastholder den Antagelse, at Navnet Slesvig kun har varet knyttet til en Bebyggelse nordfor Slien og at Navnet Hedeby forst ved Halvkredsbyens Undergang i 11. Aarh. er blevet sat i Forbindelse med Slesvigs. - Jfr. især Elis Wadstein: Norden och Vasteuropa i gammal tid 1925, S. 60 ff: samme i Fornvännen 1932, S. $220 \mathrm{ff}$; 0 t t o $\mathrm{Sch}$ e e 1 i Zaitschr. f. Kirchengeschichte L, 1931, S. $2 \pi \mathrm{ff}_{\text {.; }} \mathrm{Sch}$ wantes i Zeitschr. f. Ethnologie 1931, s. 246 ff.; J a n k u h $\mathrm{n}$ i Nordelbingen 9 , 1934. S. 365 ff.; l a C o u r i Sønderjyll. Hist. I., S. 250.

4.) Quellen S. 131.

46) Quellen S.. 132 . 
Slesvig-Hedebys Opkomst skyldtes især dens Forbindelse med D o res t a d ved Utrecht, Nordeuropas vigtigste Handelsplads i 8. og 9. Aarhundrede. Denne Forbindelse styrkedes, som det fremgaar af "Ansgars Levned", ved den kristne Mission fra Midten af 9. Aarhundrede. Herefter var det, at Købmænd baade fra Hamburg og fra Dorestad uden Frygt drog til Slesvig, hvor der snart fandtes Overflod paa alt. Slesvig laa paa Vejen til det svenske Birka, hvis livlige Handelsforbindelse med Dorestad "Ansgars Levned" fremhæver. - Det stærkeste Vidnesbyrd om Betydningen af Slesvigs Forbindelse med Dorestad er, at man til Forbillede for de æoldste nordiske Mønter, der i 9. Aarhundrede cirkulerede i Hedeby, tog Mønter, som Karl den Store havde ladet præge i Dorestad fra 8. Aarhundredes Slutning. Paa disse barbariske Efterligninger er Originalreversens (Dor-)stat udartet til et -tat, der nærmest ligner en Bygning med Port. ${ }^{47}$ )

De frisiske Købmænd fra Dorestad har medvirket stærkt ved sachsiske Byanlæg i 8. Aarhundrede som Bremen, Verden, Bardowik o. fl. Det er blevet formodet, at ogsaa de staar bag ved de Markedspladser i Norden, der snart udviklede sig til Smaabyer. Baade Birka og Slesvig-Hedeby er yngre end Dorestad, næppe ældre end fra omkring 800 .

Slesvig-Hedeby opstod paa det Sted, hvor den frisiske Købmand paa sin Vej mod Østersøen havde den korteste Passage, livis han vilde undgaa den langvarige og farefulde Rejse omkring Skagen. ${ }^{47}$ ) Hans Skib kunde fra Dorestad sejle langs den frisiske Marskkyst lige op til Ejderen og op ad denne ind $i$ Trenen til Hollingsted. Herfra var Afstanden over Land til Halvkredsvolden kun $16 \mathrm{~km}$.

Endnu i 12. Aarhundrede var $\mathrm{H}$ oll in $\mathrm{g} s \mathrm{t}$ e d det naturlige Omladningssted for Transithandelen fra Utrecht, Dorestads Af-

${ }^{47)}$ Jfr. H a n s I i l d e bra n d i KgI. Vitterh. Akademiens Månadsblad $1885, S$. 122 ff. (hævder at Monterne er præget i Birka), P. H a uberg i Aarboger f. nord. Oldk. 1914, S. 76 ff. (havder, at Mønterne er præget i Hedeby). Spørgsmaalet om Prægningsstedet lader sig endnu ikke afgøre.

as) Jfr. Fi: i is W a dstein: Norden och Västeuropa i gammal tid, 1925, S. $65,72$. 


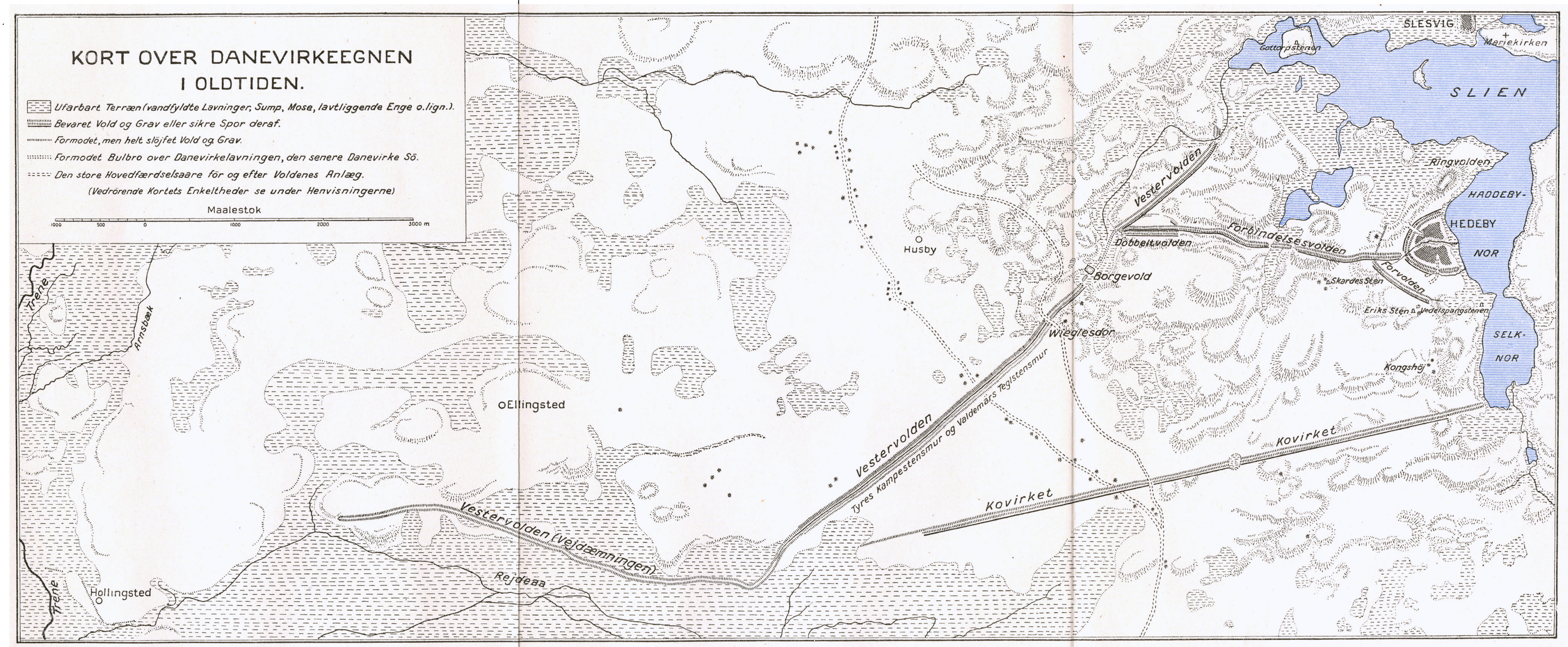


løser, og Deventer med Slesvig som Maal. Man har nu i Hollingsted ganske nær ved Trenen paavist »sort Jord ", indeholdende Potteskaar bl. a. af Lervarer importeret fra Rhinegnene i 9. Aarhundrede og desuden Slagger fra Metalarbejder. ${ }^{48}$ )

Fra Hollingsted er Handelsvejen gaaet over Land, antagelig langs Danevirkes Hovedvold til Slien ved Slesvig-Hedeby. Ved Kalegat (»Røde Kro«) har den krydset den gamle $\mathrm{H}$ æ r v e j eller Oksevej, der gik fra syd forbi Slesvig til Viborg langs Jyllands Højderyg. En islandsk Vejviser for Pilgrimsrejsende fra Middelalderen anviser fra Island og Norge Vejen over Aalborg og Viborg; derfra - siger Vejviseren - er der en Uges Rejse til Hedeby." ${ }^{50}$ Paa Byplaclsen bag Halvkredsvolden har man nu fundet et Lukasemblem fra 11.-12. Aarhundrede, der har været anvendt som Pilgrimstegn. ${ }^{51}$ )

Ad $S ø v e j e n$ nordfra gemmem Kattegat og Lillebalt er norske Farmand - ligesom $\mathrm{Ot}$ t a $\mathrm{r}$ - draget fra $\mathrm{Sk}$ i $\mathrm{r}$ ing ssal til Hedeby; deres vigtigste Eksportvare har foruden Vægstensgryder, der $\mathbf{i}$ stor Mængde er fundet $\mathbf{i}$ Hedeby, været Pelsværk, som ogsaa Ottar medførte paa sin Rejse helt fra HaalogaLand. Denne Vare har de frisiske Købmand taget i Bytte for deres Salt og Tøjer.

Fra Hedeby er mange i Wulfstans spor sejlet til Truso. Den sydlige Ostersøkyst mell dens Skovprodukter har spillet en stor Rolle i Østersøhandelen. Foruden R e ri c, hvis Købmænd Godfred flyttede til Sliestorp, var Julin eller J u m n e i Pommern, Truso i Preussen og Se eburg i Kurland vigtige Pladser, omtalt i santidige litterære Kilder. Levninger af Vikingetidens Havnepladser paa Østersøens Sydkyst er i de senere Aar blevet fremdraget af tyske, lettiske og litauiske Arkæologer; den svenske Arkæolog B i r g r N e r m a n mener i Grobin ved Libau i Letland at have fremdraget Havnebyen

49) Om IJdgravninger se J a $\mathrm{n} \mathrm{k}$ u h $\mathrm{n}$ i Kieler neueste Nachrichten 16/10 1932. (Om Transitvejen Hollingsted Slesvig se Fr. Frahm i Zeitschr. f. Schl.-Holst. Feschichte 60, 1930, s. 1 ff., 62, 1934, s. $160 \mathrm{ff}$.

$\left.{ }^{50}\right)$ Quellen S. 140. Orn Kildestedet, der noppe stammer fra 12. Aarh., se F ra h m i Zeitschr. f. Schl.-IIolst. Gesch., 1934, S. 179 f.

51) Jfr. J a n k u h n i Nordelbingen 9, S. 362. 
Seeburg, som omtales i "Ansgars Levned". Ved A pu ol é i Lithauen og ved $W$ is $k$ ia $u$ te $n$ ved Kurisches Haff har Nerman fremdraget "svenske Kolonier" fra 9.-10. Aarhundrede. ${ }^{.2}$ )

Fra Østersøen fulgte Købmændene de store Flodveje, der førte ind i Rusland og holdt Europa i Forbindelse med Orienten paa denne Kant. Forbindelsen med Orienten er langt stærkere afspejlet i S verig e end i Hedeby. Kun yderst faa arabiske og byzantinske Mønter er fundet i Hedeby.

Nermans arkæologiske Undersøgelser i det østlige Østersøomraade og Russeren $\mathrm{R}$ a u d on i k a s' i Ladogaomraadet vidner om en ret kraftig svensk Ekspansion i disse Egne i Vikingetiden, et Sidestykke til dansk og norsk Ekspansion mod Vest. ${ }^{53}$ ) Overalt paa Østersøens Kyster og især ved Flodvejene har S v e nskerne vidst at sætte sig i Besiddelse af strategiske Punkter, hvorfra de kunde beherske Handelsvejene til egen Fordel. Ogsaa $\mathrm{H}$ ed eby har antagelig en Tid været underlagt svensk Herredømme.

Efter Adam af Bremens rigtignok forvirrede Udsagn har Chnob (d. v. s. Gnupa) tilhørt et indfødt svensk Dynasti; dette synes at have behersket Hedeby $i$ første Halvdel af 10 . Aarhundrede - samme Tidsrum, som Baadkammergraven henføres til. Dette svenske Herredømme har dog ikke længe ladet sig opretholde. Hedeby er sikkert i 934 blevet erobret af $\mathrm{H}$ e nrik I, og naar Hara l d Gor m søn paa Jellingestenen - vel i 980'erne - roser sig af at have samlet "alt Danmark «, betyder dette vel snarest, at han har faaet Hedeby $i$ sin Magt. ${ }^{54}$ )

At Hedeby har været udsat for endnu et heldigt Angreb, derom vidner i hvert Fald den Runesten - "Hedebystenen" der vel kort efter Aar 1000 er rejst af Torlv, Svens Hird-

52) Fundene især i Wiskiauten har et udpræget "svensk Garnisonspræg". Jfr. Nerman i Eurasia Septentrionalis antiqua IX, 1934, S. 357 ff.

${ }^{53}$ ) W. J. R a u donikas: Die Normannen der Wikingerzeit und das Ladogagebiet 1930 (Kgl. Vitterhets Akademiens Handlingar 40:3).

54) Om Fortolkningen af de herhenhørende Kilder staar der stadig Strid. Af den vidtløftige Litteratur kan her kun anføres: $L$ is T a c o b s e n: Svenskevaldets Fald 1929, S. 19 ff., jfr. S t u re B olin i Scandia IV, 1931, S. 184 ff. og Vilh. I a c:o u r, i Aarh. f. nord. Oldkyndighed 1934 S. 5.j ff. 
mand, efter hans Fælle Erik, "som døde, da Drenge sad om (d. v. s. belejrede) Hedeby; men han var Styresmand, en velbyrdig Dreng«. Det er uvist, om denne S ve n eller den K ong $S$ ve $n$, der ved Hedeby har rejst $\sin$ afdøde Hirdmand $S \mathbf{k}$ a $\mathbf{r}-$ d e, som havde været i England, en Mindesten ("Danevirkestenen «), er identisk med S v e $\mathrm{T}$ ves $\mathbf{k} æ \mathrm{~g}$, men Stenen viser, at $\mathrm{Hedeby}$ endnu ved Begyndelsen af det 11. Aarhundrede har været rig nok til at vække en Krigerkonges Erobringslyster. ${ }^{55}$ )

Med det 11. Aarhundrede var Hedebys bedste Tid dog omme. Man har paa dens Grund kun fremdraget faa Fund fra 11. Aarhundrede. Aarsagen til $\mathrm{H}$ e d e b y $\mathrm{s} \mathrm{N}$ e d $\mathrm{g}$ a $\mathrm{n} \mathrm{g}$ efter Aar 1000 er ikke klar. Vesteuropas Handel med Byzans og Araberne havde fundet bekvemmere Veje end Vejen over Østersøen, men langt farligere for Hedeby har det været, at der med Opblomstringen af Dinants Bronzeindustri og Harzens Sølvbjergværker krævedes en sydligere Handelsvej fra Vest til Øst; dens Østersøhavn blev fra $1143 \mathrm{~L}$ ü b e c k, og V is by blev Hovedcentret i Østersøhandelen.

Skønt Verdenshandelen havde fundet andre Veje, tabte Slien langtfra sin Betydning for Handelen. En ny By voksede op paa Nordsiden af Slien og overtog den gamle Bys efterhaanden mere begrænsede Opgaver. Den overtog ogsaa dens Dobbeltnavn. Til Forvirring for senere Tiders Historikere kaldtes ogsaa denne By baade Slesvig og Hedeby. ${ }^{\text {s. }}$ )

13. Hedeby og Danevirke.

Ved Forbindelsesvolden, der strækker sig fra Halvkredsvolden mod Vest til Danevirke Sø, har Fæs tningen Hedeby været knyttet til Danevirkes Hovedvold, der gaar fra Borgvolden ved Danevirke Sø (kaldet "Thyraborg «) mod SV og V over Kalegat til Engdragene ved Hollingsted. Fra Danevirke Sø sender Volden en østlig Udløber, "N ordvol-

55) Jfr. L is J a c obsen i Scandia V, 1932, S. $112 \mathrm{ff}$.

sB) Jfr. Sch w antes i Zeitschr. f. Ethnologie 1931, S. 250; Fr. F r a h m i Zeitschr. d. Gesellsch. f. Schlesw.-Holst. Geschichte 62, 1934, s. $170 \mathrm{ff}$. 
d e n«, op til Gottorp Enge. Et Stykke sydfor disse Anlæg ligger som en fremskudt Voldlinje det lave Kovirke, der fra Selk Nor strækker sig snorlige $6^{1 / 2} \mathrm{~km} \bmod \mathrm{SV}$ til Rheideaaengene, hvor det maaske oprindelig har haft Tilslutning til Hovedvolden..$^{57}$ )

For den historiske Videnskab er det endnu en Gaade, hvad Sammenhængen med disse Voldanlæg har været. I de litterære Kilder fra før Aar 1000 findes Voldanlæg ved Slien kun omtalt ved 2 Lejligheder.

Først ved 808, da Danernes Konge G o d f r e d ifølge de frankiske Rigsannaler besluttede "at befæste sit Riges Grænse mod Saksland ved en Vold, saaledes at denne Befæstning fra den østlige Havbugt, som man kalder Østersalt, lige til Vesterhavet kunde værne hele den nordlige Bred af Ejderfloden, $\rightarrow$ og den skulde kun have een Port, hvorigennem Vogne og Ryttere kunde fardes frem og tilbage." Af den Sammenhæng, hvori denne Meddelelse staar, fremgaar, at Godfreds Vold især har skullet beskytte "den Havn, som hedder Sliestorp«. Men hvor Sliestorp har ligget, ved vi ikke. Har det ligget, hvor Slesvig nu ligger, er Godfreds Vold snarest den Vold, der gaar fra Gottorp over Danevirke Sø til Hollingsted, - men laa Sliestorp ved Haddeby Nor, har Kovirke eller maaske Forbindelsesvolden til Danevirke Sø og Hovedvolden derfra vestpaa været Godfreds Vold. I saa Fald er Nordvolden fra Danevirke Sa til Gottorp et Anlæg fra en antagelig senere Tid, da en Bebyggelse paa Sliens Nordside skulde beskyttes. I hvert Fald er Annalernes Opgivelser om Beliggenheden af Godfreds Vold saa vage, at man ikke med Sikkerhed kan knytte Godfreds Navn til noget bestemt af de bevarede Voldpartier. ${ }^{58}$ )

57) Hovedværket om Danevirke er endnu: S ophus Müller \& Carl Ne ergaard: Danevirke, archæologisk undersøgt, beskrevet og tydet, Nord. Fortidsminder I, 1903. Problemer vedr. Danevirke er fornylig belyst af Fr. F r a h m i Nordelbingen 9, 1934, S. 370 ff. En indgarende Redegørelse for Voldkompleksets enkelte Dele vil fremkomme i 1. Bind af den store Hedebypublikation: "Die Ausgrabungen in Haithabu«, ved J a $\mathrm{n} \mathrm{kuhn.}$

${ }^{58}$ ) Quellen S. 25 f. Jfr. J a n k u h n i Nordelbingen 9, 1934, S. 366. 
Anden Gang næunes en Befæstningslinje ved Slien 974, da Danerne - ifølge den sachsiske Krønikeskriver $\mathrm{T}$ h i e $\mathrm{t}$ m a r a f M e r s e b u r g - havde gjort Oprør mod den tysk-romerske Kejser $\mathrm{O}$ t to I I. Kejseren ilede med en Hær til Slesvig. Her fandt han "den Grav, som er gjort til Fædrelandets Forsvar og den Port, som kaldes Wiegslesdor" besat af Fjender, hvis Front han dog gennembrød ved et dristigt Angreb. ${ }^{59}$ )

Dette er alt, hvad paalidelige litterære historiske Kilder kan oplyse om Voldkomplekset ved slien - før Valdemarstiden. Disse knappe Meddelelser er ikke i Stand til at skaffe os Klarhed vedrørende Anlæggenes Formaal.

Medens den arkæologiske Forskning har kumnet give os en Fylde af Oplysninger om $\mathrm{Hede} b \mathrm{y}$, har den $\mathrm{i}$ langt mindre Grad gjort Fyldest overfor Dan evirke problemerne. Dette skyldes især den Kendsgerning, at der indtil 1931, saa utroligt det lyder, ikke havde fundet videnskabelige Udgravninger sted i Danevirkekomplekset - undtagen i Forbindelsesvolden, Forvolden og Kovirke. ${ }^{80}$ ) Alle de undersogte Voldpartier i Danevirke: Hovedvolden, Nordvolden, Forbindelsesvolden, Forvolden og Kovirke har haft Grav, d. v. s. Front mod Syd. Af størst Interesse for Sammenhængen med Hedeby er Paavisuingen af, at Danevirkes Hovedvold oprindelig har strakt sig helt til Hollingsted $i$ Vest, og af at den - i hvert Fald paa en Strokning ved Rheideaa - har haft Karakter af en Vej beskyttet af et Palisadeværk.

Et Snit gennem Volden $\mathrm{S} \emptyset$ for Ellingsted viste, at Volden her var bygget op i mindst to Tempi. Paa begge Stadier havde Volden beskyttet en lavere Terrasse paa Nordsiden - utvivlsomt en Vej. ${ }^{{ }^{11}}$ )

Dette er alt, hvad vi ud fra historiske og arkæologiske Kilder kan vide om selve Danevirke. Det eneste sikkert daterede Afsnit af Voldene er $\mathrm{V}$ a l de mar den $\mathrm{St}$ ore s Teglstensmur, ler er bygget oven paa ældre Voldanlæg. Hovedvoldens Sam-

${ }^{58}$ ) Quellen S. $83 \mathrm{f}$.

$\left.{ }^{60}\right)$ Jfr. S ch w a n te s i Zeitschr. f. Ethnologie 1931, S. 252.

61) J a k uhn i Nordelbingen 9, 1934, S. 367. 
menhæng med Hedebys Voldsystem stammer dog utvivlsomt fra denne Bys Stortid.

Kun for en spansk Araber har Slesvig eller Hedeby syntes en fattig By; for germanske Fyrster har dens rige Toldindtægter været et fristende Bytte, og Byen er let blevet inddraget i de Grænsekampe mellem Daner og Sachser, der har fundet Sted $\mathrm{i}$ disse Egne. Paa A n s g a r s Tid fandtes en Jarl (comes) i Slesvig; i første Halvdel af 10. Aarhundrede har Gnupas Kongeæt behersket Byen. I 934 blev Kong Chnuba og hans Daner gjort skatskyldige; 974 gjorde Danerne Oprør, og Kejseren straffede dem. Vel i Begyndelsen af 11. Aarhundrede har Kong Sve n belejret og erobret Byen.

Det har ikke blot været Byen selv, der har været omstridt, men ogsaa dens Interessesfære og da sikkert især Handelsvejen fra Hollingsted til Slesvig-Hedeby. Om ikke denne Vej har været den, der paavistes ved Ellingsted, er det i hvert Fald sandsynligt, at et af "Danevirkes" Formaal i 9. og 10. Aarhundrede har været at værne denne Handelsvej - Hedebys Handelsvej mod sydfra kommende Fjender.

Roar Skovmand. 